\title{
ARIANISM IN ENGLISH NONCONFORMITY, 1700-1750
}

\author{
DINU MOGA* \\ Emanuel University of Oradea
}

\begin{abstract}
During the time of English Nonconformity, Arianism was not only embraced, but openly acknowledged by most of the Presbyterian ministers. That generation of ministers, who contended so zealously for the orthodox faith, had finished their labours, and received from their Lord a dismissal into eternal rest. Those champions among the laity who, at the beginning of the controversy, stood up so firmly for the truth, had entered as well into the joy of their Lord. Though their children continued Dissenters, too many of them did not possess the same sentiments or spirit. Among those who succeeded these ministers were too many who embraced the Arian creed. To this unhappy change contributed the example and conversation as well of many from the younger Presbyterian ministers. In consequence Arianism spread far and wide in the Presbyterian congregations, both among the ministers and the people. This unhappy controversy proved the grave of the Presbyterian congregations, and of those of the General Baptists. The effects of Arianism, though at first scarcely visible, gradually produced desolation and death.
\end{abstract}

KEYWORDS: Arianism, controversy, nonconformity, creeds, consubstantiality

\section{Introduction}

The apostolic teaching about Christ was relatively simple. But what the apostle taught about Christ also contained ideas that some people found difficult to understand. While the history progresses after the time of the apostles, we learn that prior to the beginning of the fourth century all creeds and summaries of faith were local in character. It was taken for granted, of course, that they enshrined the universally accepted Catholic faith, handed down from the apostles (Kelly 1960: 205). The early catechetical summaries were known by such names as 'the rule of faith', 'the canon of the truth' and these were names which carried with them the idea of the exclusion of errors and the writers who used them were conscious of possessing the apostolic deposits of the Christian truth in contradistinction to the false speculations of heretical sects. But soon the early church began to have struggles with theological issues.

* DINU MOGA (MTh in Historical Theology, Westminster Theological Seminary, 2005; PhD in Theology, Babeș-Bolyai University, 2015) teaches Systematic and Historical Theology at Emanuel University of Oradea. Email: mogadinu@gmail.com. 
By the fourth century so called the Arian controversy was coming to the forefront. Arius (c. 250-c. 336), an Alexandrian Priest and a bright scholar who had trained at the theological school of Antioch, along with his companions, concocted a creed-like summary of their theological position and sent it to Alexander, bishop of Alexandria (Bray 1984: 106ff). The issues presented by Arius concerned the nature of Christ. The questions being asked by him and his adherences were: Who was Christ? What was He in relation to God the Father? Is He different in essence or is He one and the same essence? Is He a creature or is He the Creator? etc. Thus, the problem of the relationships within the Godhead and the nature of Christ came to be called Christological Controversies. Arianism was one of these controversies.

In what follows this paper will take into considerations the following matters: firstly, a brief look at the early roots of Arianism, secondly, an examination of the way Arianism was addressed in the time of the reformation and thirdly, an examination of Arianism in the English nonconformity between 1700 and 1750. As we conclude, we shall make some final remarks on this study.

\section{The Early Roots of Arianism}

Arianism, also called 'the great trinitarian strife' (Berkhof 1963: 88). or 'the greatest theological controversy in the history of Christianity' (Needham 2000: 201), takes us into the study of the doctrine of the Trinity in the history of the early church, because Arianism is a fourth-century Trinitarian heresy that denied the divinity of Christ, the second Person of the Trinity.

Berkhof explains that the doctrine of the Trinity had not been greatly discussed by the early Church Fathers. It came really to front for the first time in this Trinitarian controversy between Arius and Athanasius (Berkhof 1959: 87-91). He notes again that until the time of Tertullian, Christ, or Logos, has been conceived by some as impersonal reason, while others regarded Him as personal and co-eternal with the Father, sharing the divine essence, and yet ascribing to him a certain subordination to the Father (Berkhof 1963: 82). With respect to the Holy Spirit it is suggested that He occupied no important place in their discussions. Some considered him to be subordinate, not only to the Father, but also to the Son (Grudem 1994: 245). Other represented Him as a divine influence or a mode of manifestation assumed by the Godhead.

But Arianism held that the Father alone was the eternal and true God, because He alone, in the full sense of the word, was ungenerated. Concerning the Son, the Logos, who had become flesh in Christ, Arius taught that, inasmuch as Christ was generated, He could not be God. He had to be a creature who had been made before other creatures, but nevertheless made as the others were made through the will of God. With respect to the Holy 
Spirit Arius held that He was a creature or else a quality or attribute of God. This teaching was nontrinitarian and ultimately destructive to the whole Christian faith. [For the details regarding the Arian theology, see an extensive and helpful treatment in Kelly (1960: 231-262). For a much briefer treatment of the Arian formulation, see Macleod (1996: 122-124).]

If Arian heresy is accepted, it means that Christ could not redeem fallen humanity. The Arian controversy has been opposed first by his own bishop, Alexander, who contended for the true deity of Christ, but received a hostile response from Athanasius, who argued that the divinity of Christ was of central importance to the Christian understanding of salvation. He maintained that to regard Christ a creature was to deny that faith in Him brings man into saving union with God. He strongly emphasised the unity of God and insisted on a construction of the doctrine of the Trinity that would not endanger this unity. But while stressing the unity of God, Athanasius also recognized three distinct hypostases in God. According to him the unity of God as well as the distinctions in His Being are best expressed in the term 'oneness of essence' (Berkhof 1960: 90).

His fundamental position stated that union with God is necessary unto salvation and that no creature but only one who is Himself God can unite us with God. Athanasius argued that the only possible solution is to accept Jesus as God incarnate. The logic of his argument would be that no creature can redeem another creature. If, according to Arius, Jesus Christ is a creature, Jesus Christ cannot redeem humanity. Athanasius argued that only God can save and if Jesus saves it means that Jesus is God.

When Constantine conquered the Eastern half of the Roman Empire in 324 A.D., he found the Eastern Church divided by this controversy. Therefore, in 325 A.D. Constantine called together the Council of Nicaea and asked those summoned to sort out this Christological disagreement. [See Bray (1984: 108); other details regarding the controversy and the events which led to the Council of Nicaea are also offered by Needham (2000: 201212); see also Grudem (1994: 243-244). For much more details regarding the Council of Nicaea, the bishops who attended the council and other details related to the creed formulation, see Kelly (1960: 208-230).] Constantine's object in summoning the council was to consolidate the Church, which in his eyes represented the spiritual aspect of his empire, based on the widest possible measure of doctrinal unity. The council met at Nicaea on 19 June 325 and settled the Arian controversy affirming that Jesus was homoousios (one in being or of one substance) with the Father, thus rejecting the Arian position and asserting the divinity of Christ. [Kelly explains that according to Socrates its opening session was held on 20 May 325, but it has been shown that the true date was 19 June (Kelly 1960: 211).] 
Although the Council of Nicaea seemed to have settled the Arian controversy and restored unity and peace to the Eastern Church, this appearance was deceptive. The Eastern Church was divided into three parties. Besides the Arian and Athanasian contending parties there was a third party called the Origenist party which accepted the traditional Eastern theology of Origen. [For a detailed and extremely helpful account on Origen and all the issues discussed so far, see Bray (1984: 76-91).]

Although at the Council of Nicaea they have accepted the word homoousios, later they had serious doubts about its use due to the fear that it would open the door to Sabellianism. Sabellianism, or Modalism, held that Father, Son and Holy Spirit were but three names for one and the same God-a God who had made Himself known thus successively as His revelation progressed in various forms and manifestations.

Thus, we see that while Arianism tries to maintain the oneness of God by placing Son and Spirit outside the Divine being and reducing these to the level of creatures, Sabellianism tries to arrive at the same end by robbing the three persons of the Godhead of their independence. This is done by metamorphosing the persons into three successive modes of revelation of the same Divine being.

Therefore, they came up with the suggestion that the word homoousios be replaced by the word homoiousios, to teach that the Son is of a similar substance with the Father not the same substance. This meant that the Son, although uncreated and divine, was inferior to the Father in His divine nature.

From here onwards we see how two distinctive approaches gradually emerged. The Origenist party formed the majority in the East and continued to hold an important position within the Orthodox churches of today. This position has been developed by a group of three writers: Basil of Caesarea (c.330-379), Gregory of Nazianzus (329-389), and Gregory of Nyssa (c. 330-395), known as the Cappadocian fathers. The West, however, took a different view and was loyal to the Council of Nicaea. They developed a type of theology that was more in harmony with the views of Athanasius. [A more detailed account of the two positions is presented in McGrath (1998: 61-67); Berkhof (1960: 91-97).]

In 381 A.D. the general Council of Constantinople met and under the guidance of Gregory of Nazianzus declared its approval of the Nicene Creed and affirmed the deity of the Holy Spirit.

We notice, therefore, that what had started as a dispute about the status of Christ finally became a search for a full doctrine of the Trinity. Arianism was very slowly breaking down after the fourth century but is has never been totally extinguished (Macleod 1996: 124). Bray notes that the last Arians were forcibly converted after the Third Council of Toledo in 589 (Bray 1984: 108). But such an event has not proved itself to be completely success- 
ful, as was noted above, and Arianism had the tendency to come to the surface in various places, as for example Spain.

Bray also notes that the last time when we hear about it is in 794 when 'it was anathematised by Charlemagne at the Council of Frankfurt' (Bray 1984: 108).

When we come to the Reformation period, we find that the doctrine of the person of Christ was not in the foreground (Berkhof 1959: 118). It received its complete definition in the Second Helvetic Confession, prepared in 1566, where Arianism is completely denied. Berkhof quotes extensively from this Confession, but here we shall reproduce only the part which makes a direct reference Arianism. He says:

Therefore, the Son of God is co-equal and consubstantial with the Father, as touching His divinity; true God, and not by name only, or by adoption, or by special favour, but in substance and nature... We therefore do abhor the blasphemous doctrine of Arius, uttered against the Son of God... (Berkhof 1959: 120).

\section{Arianism and the Reformers' Writings}

One of the characteristics of the Reformers was their interest in a theocentric theology. The Reformers were, therefore, concerned with the worship of a Triune God who created all things and who made Himself known in Jesus Christ and who, as the Holy Spirit, is the Lord and the Giver of life (Leith 1978: 67-83 and 95). They work out their theological formulation within the context of what was going on in the theological camps before them and as a part of the theological tradition which preceded Reformation and even the Middle Ages. The reformed thinkers such as Calvin, Owen, Turretin and Bavinck were working their Trinitarian views 'in terms set by classic Trinitarian and Christological formulations of the early church'. [For a more detailed presentation of Owen roots in western tradition, see Trueman (1998: 29-46).] This aspect is important due to the fact that they were condemned by heretics, such as Arians and Sabellians, for using 'foreign terms fashioned by the human mind'. There is no doubt that for the Reformers the words of Scripture were the ultimate norm of their theology, but these great human formulations of the faith were important to them only because they faithfully reflected the position of the Scriptures themselves. John Calvin (1509-1564) answers by making a distinction between what can be rightly or wrongly called 'foreign'. Thus, he says:

If they call a foreign word one that cannot be shown to stand written syllable by syllable in Scripture, they are indeed imposing upon us an unjust law which condemns all interpretations not patched together out of the fabric of Scripture. But if that is 'foreign' which has been curiously devised and is superstitiously de- 
fended, which conduces more to contention than to edification, which is made use of either unseasonably or fruitlessly, which by its harshness offends pious ears, which detracts from simplicity of God's Word-I wholeheartedly embrace their soberness. [See Calvin (1960: 124) and Bray (1984: 86), where he draws attention to the way in which Calvin dealt with charges brought by Arius against those who use terms like trinity and consubstantial (homoousios) in dogmatic theology on the ground that they were alien impositions on scriptural thought.]

In his attitude towards the doctrines of the early church Calvin regarded himself as 'a hearer of the Word who belongs to the multitude of those who have interpreted Scripture before him' (Niesel 1980:54). He expresses his appreciations for the 'men of old' who, 'stirred up by various struggles over depraved dogmas, were compelled to set forth with consummate clarity what they felt, lest they leave any devious shift to the impious, who cloaked their errors in layers of verbiage' (Calvin 1960: 124-125).

Calvin's aim is to defend the Biblical message against the 'great battles' always instigated by Satan in order to 'tear our faith from its very roots' (Calvin 1960: 145). Calvin sees as being vital to establish a correct representation of the doctrine of the Trinity. For him this is the only way in which the gate can be closed not only to 'Arius and Sabellius, but to other ancient authors of errors' (Calvin 1960: 147). How can we do this, asks Calvin? His answer is by 'holding fast to what has been sufficiently shown from Scripture: that the essence of the one God is simple and undivided, and that it belongs to the Father, the Son, and the Spirit; and on the other hand, that by a certain characteristic the Father differs from the Son, and the Son from the Spirit' (Calvin 1960: 147).

John Owen (1616-1683), another great Reformed theologian, in his writing makes a direct attack on the doctrines of the Arminians and Socinians, which at the time were more prevalent that Arianism, but with the same devastating effects. [Eveson (2000: 28-31) produced a valuable summary of the historical context for John Owen's doctrine of justification.]

In Owen's conflict with the Socinians the main topic of debate is Christology and consubstantiality of the Father and the Son with serious implications on the orthodox doctrine of the Trinity (Trueman 1998: 151). Owen understood that these heretics were referring to Scripture passages, also quoted by the Arians, which seem to represent the Son as inferior to the Father. [For a list of the passages used by Arians see Berkhof (1959: 89).] Their basic idea suggests that Christ is not essentially God but earns his position as Son of God through his work. [See Trueman's detailed discussion about the Socinian criticisms of orthodox Christology (Trueman 1998: 152154).]

In their attacks on the divinity of Christ the Socinians denied His equality with the Father and the possibility of the existence of two substances in 
one person-one human one divine-without any conflict between them. The issue of the consubstantiality of the Father and the Son points towards two other important theological issues which Socinians deny: the eternal pre-existence of Christ and the role of Christ in creation (Trueman 1998: 157-164). Such attacks were viewed by Owen as attempts to undermine Trinitarianisms, because the denial of the consubstantiality of the Father with the Son led to a denial of the full humanity of Christ and his agency in creation and in the work of redemption.

When Francis Turretin (1623-1687), another famous Reformed theologian, proposes to deal with the subject of the Holy Trinity he sees the subject as being important for discussions not because this 'adorable mystery' can be proved, but because the authority of the divine revelation alone proposes it to be received by faith and adored with love (Turretin 1992: 253). While he does this, Turretin explains the meaning of the words which describe the Trinity (Turretin 1992: 253-257). He is likewise concerned to say a few things about their use, and this concern has aroused from the importunity of the heretics who he identifies as the Arians, Sabellians and other anti-Trinitarians such as Socinians and the Arminians, who in fact agree with the first (Turretin 1992: 257-258).

Another leading theologian closer to our times was Herman Bavinck (1854-1921), a theologian of the neo-Calvinist revival initiated a century ago in the Dutch Reformed Church (Elwell 1984:129). In his scholarly work (Bavinck 1956) he showed a remarkable sensitivity to nineteenth century developments. His first concern was to apply the full scholarly resources of his own age to a renewal of the dogmatic tradition represented by seventeenth century Reformed scholastic theology. Like all the others reformed theologians before him, Bavinck always insisted on the primacy of Scripture. He too traces back the historical battle against the doctrine of the Trinity and speaks about two major views which contradict this truth-Arianism and Sabellianism-and then cautions the church about the importance of guarding the truth against these anti-trinitarian views (Elwell 1984: 156158; see also Bavinck 1956: 143ff).

In conclusion, we notice that all these reformed theologians wrote as churchmen, concerned with preaching, worship and pastoral care. But they also wrote as good exegetes of Scripture which was stimulating intellectually and challenging spiritually. They were all aware of the fact that an incorrect presentation of the doctrine of the Trinity will directly affect the standing ground of the believer-the message of the Bible. And without a defence of this doctrine a whole range of other doctrines are severely affected.

Therefore, the reformed theologians knew that by its confession the church is able, on the one hand, to take a strong position against the here- 
sies of Arianism, Modalism, Socinianism, and on the other hand, to influence a correct understanding of other important doctrines of the Bible.

The reformed theology maintains both the unity and diversity in the being of God. The Divine being is one: there is but one Being that is God and that may be called God. They showed that the unity of the world, of mankind, of truth, of virtue, of justice, and of beauty depends upon the unity of God. The moment that unity of God is denied or under stressed the door is open to polytheism.

The reformed theologians explained that according to Scripture, this unity comprises difference, or distinction, or diversity. It is that diversity which comes to expression in the three persons or modes of being of God. These three persons are not merely three modes of revelation. They are modes of being. Father, Son and Spirit share one and the same Divine nature and characteristics. God is our Creator who brought us into being by His will as creatures distinct from Him in kind. He is our Redeemer who saves us by the riches of grace. He is our Sanctifier who dwells in us as in His temple. As the triune God He is one God and is above us, for us, and in us.

\section{Arianism in English Nonconformity, 1700-1750}

The Rise and Spread of Arianism in Nonconformity

In their account about the rise and development of Arianism Bogue and Bennett explain that this heresy died in a series of years after the fourth century and almost no Arian was to be found for centuries (Bogue and Bennett 2001: 119). By the time Reformation was established, Arianism revived again, but with negligible success. In England Macleod explains that Arianism had been influenced by its continental supporters, especially Dutch theologians (Macleod 1996: 124) but it failed to create great numbers of supporters.

Michael Watts shows that two forms of anti-trinitarianism flourished in eighteenth-century England, Arianism and Socinianism (Watts 1978: 371). He explains that Arian views did not gain wide popularity in England until the first half of the eighteenth-century, but Socinianism attracted several Englishmen during the intellectual turmoil of the 1640s and 1650s (Watts 1978: 371-372).

After 1662 Thomas Firmin, a wealthy London silk merchant and philanthropist, financed the publication of a series of anti-trinitarian tracts which appeared in the late 1680s and 1690s (Watts 1978: 372). The first, A Brief History of the Unitarians, called also Socinians, published in 1687, was written by Stephen Nye, rector of Little Hormead in Hertfordshire, the Anglican grandson of that Philip Nye who, as a leading Congregationalist of the In- 
terregnum, had joined with John Owen in seeking to proscribe the Racovian Catechism thirty-five years earlier.

The bishops of $1690 \mathrm{~s}$ were alarmed at the dissemination of antitrinitarian views and tried to halt the growth of these heresies. Among the pamphlets published in reply to Stephen Nye's Brief History was A Vindication of the Doctrine of the Trinity by William Sherlock, dean of St. Paul's, who so overstated his case that he unsettled the orthodoxy of two Dissenters. These were William Manning, an ejected minister of Peasenhall in Suffolk, and his friend Thomas Emlyn, pastor to a Presbyterian meeting in Dublin.

Manning embraced the very Socinian views which Sherlock had sought to refute and persuaded Emlyn to go part way with him along the road from orthodoxy. Emlyn could not be brought to doubt the pre-existence of Christ, but he did adopt Arian views, and when he acknowledged his heterodoxy in 1702, he was dismissed from his Dublin pastorate. Before his return to England Emlyn defended his position in A Humble Inquiry into the Scripture Account of Jesus Christ, for which he was prosecuted and suffered two years in prison. After his dismissal from the Presbyterian church and imprisonment for propagating Arian views Emlyn retired to London where, even after the Salters' Hall dispute, none of the Dissenting ministers dared ask him to preach from their pulpits except for a few heterodox ministers of the liberal Baptist church. It must be mentioned here that it was Emlyn's Arianism which became the prevailing heresy of the early eighteenth century.

As this controversy continued renown thinkers such as William Whiston, who succeeded Isaac Newton as Professor of Mathematics at Cambridge, continued to propound Arian views. Whiston drew his system of Arianism from a work called the 'Apostolical Constitutions' which Whiston regarded it to be of equal authority with the books of the New Testament, but in critics' view it was an account of no earlier date than the fourth century. According to the system devised by Whiston the Son was formed before all ages by the will and power of the Father, and the Holy Ghost, as created by the Father, by the assistance of the Son. Due to these Arian opinions in 1710 William Whiston was deprived of his chair and expelled from the university. The following year he published them in his Primitive Christianity Revived and launched them in the world.

Whiston's heretical system found a more able advocate in Samuel Clarke, a rector in London at St. James's, Westminster, who, in 1712, published The Scripture Doctrine of the Trinity. Although Clarke did not regard himself as anti-trinitarian, the conclusions reached by him in this writing came to be branded by his critics as Arians. The Father, said Clarke, is the supreme God and the Son is inferior. But he would not go as far as to say that the Son was created. Macleod explains that to some extent his objections to or- 
thodox doctrine were methodological rather than substantial (Macleod 1996: 125). According to his view the Son was divine only in so far as divinity could be communicated by the Father, who alone is unoriginated and is the final source and first cause of all that the Son and Spirit do. However, Clarke was charged with Arianism in 1714, but he denied the charges, and, when threatened with prosecution for heresy, he agreed to publish no more on the subject. Nevertheless, his book on the Trinity was widely read and because these writings were the only large systems of Arianism written by English divines, they attracted considerable attention.

In the established church the effects were not very powerful as Arian ideas did not influence the ordinary people. Some from the clergy and a few among the laity became converts to the system. But the mass of people, not being able to see any difference in preaching, did not show any concern for it.

But far more serious developments were taking place among the Dissenters. Here Arianism spread rapidly, because the Dissenters were as much concerned about religion as their teachers were, and many understood doctrines and felt an urge for theological freedom. [See Macleod (1996: 126127) for other reasons which have to do with the historical context.] Therefore, Arianism made an easy entrance among them and 'it created a convulsion in the body' (Bogue and Bennett 2001: 120). The disorganised state of the nonconformist churches, particularly the Presbyterians, led in a few years to Whiston and Clarke's books appearance in the city of Exeter under the patronage of two Presbyterian ministers, Joseph Hallet and James Pierce. Joseph Hallet was the son of an ejected minister and a pastor in Exeter since 1689 .

James Pierce was minister to one of Exeter's three Presbyterian congregations, being called there in 1713, after he was removed from Newbury. He was a very able man and had high influence among the Dissenters in that city. [For a more detailed account regarding his abilities, negative as well as positive, see Bogue and Bennett (2001: 129ff).] His acquaintance with Whiston took place while he was a minister at Cambridge but was led to Arianism reading Clarke's book on the Trinity. Bogue and Bennett explain that his acceptance of the pastoral office at Exeter was radically wrong, because before he left Newbury Pierce confessed himself to have been a convert to the opinions of Whiston and Clarke. But the Dissenters at Exeter were zealous Trinitarians, as he must have known. These are Bogue's and Bennett's comments:

To come to them in such circumstances, and to conceal his sentiments; and, by the use of ambiguous terms, to endeavour to make them believe that he held the same opinions with themselves, cannot be justified. This was the source of all the evils which followed; and, if Mr. Pierce was made to drink the cup of wormwood 
and gall, he had himself alone to blame, for disingenuously professing to be what he was not (Bogue and Bennett 2001: 129).

Towards the end of 1716 and the beginning of 1717 Arianism began to rise in Exeter above ground and a few ministers were heard to speak contemptuously with respect to the orthodox doctrine of the Trinity. They blasphemed against it and argued boldly in favour of the Arian system.

After a few attempts coming from the congregations of these ministers to make them stand up in defence of the truth and raise their voice against the supporters of errors, in the beginning of 1718, the committee appointed some of their own number to represent to their ministers the state of the city, and request them to preach in defence of the 'eternal Deity of Jesus Christ' (Bogue and Bennett 2001: 121). Their reception was unfavourable. Mr. Pierce felt insulted by the request and was unable to conceal his resentment. [For Pierce's complaints of what he calls 'their inquisitorial spirit', see Bogue and Bennett (2001: 131, 133).

The controversy was not confined to Exeter but spread over to other parts of the country and caused much trouble in the minds of all zealous ministers around. In September 1718, the Devon and Cornwall Association of Ministers and the Exeter Assembly demanded that every minister should declare his position on the Trinity. Pierce made it in his own words by stating that he believed in 'the Son and Holy Gost to be divine persons, but subordinate to the Father' (Watts 1978: 374). Hallet's position was stated wholly in the word of Scripture.

Soon after this meeting various pamphlets in favour of Arianism, some of them printed in Exeter, and others sent down from London, were circulated among the people. The impression made by these writings on the minds of the most pious and peaceable believers caused still deeper distress.

These courses of events led to such a critical situation that matters had to be also referred to other sympathizers in London. The members of the Committee of the Three Denominations decided to call a meeting of all Dissenting ministers in London and asked these to debate the 'advices' they should send to Exeter.

\section{The Meeting at Salters' Hall in London in 1719}

The London ministers summoned for the meeting have met at Salters' Hall on 19 and 24 February 1719. During the proceedings, someone proposed that their advices should be accompanied with a declaration of their own faith on the doctrine of the Trinity, motivating that such a step would give them greater weight and help to discourage the supporters of error. This proposal stirred up fierce debates and the whole Conference divided into subscribers and non-subscribers. Sixty of the ministers immediately withdrew from the assembly and met together at another place and decided to 
adopt the words of the first article of the Church of England and the answers to the fifth and sixth questions of the Assembly's Catechism, as a form of sound words in which the Scripture doctrine of the Trinity is properly expressed.

Acting now as a separate body, they drew up a new series of advices to the Dissenters of Exeter and accompanied them with the information of their steadfast adherence to the divinity of Jesus Christ. But their advices arrived in Exeter a month later and by that time the trustees of the Presbyterian meeting-houses, on the advice of the orthodox local ministers, closed their doors to Pierce and Hallet. One-year latter in 1720 the ejected ministers opened a new meeting-house where, undisturbed by the magistrate, preached to a congregation of about 300 .

In the meantime, those who remained at Salter's Hall, called now the non-subscribers, proceeded with the meeting and in an adjourned meeting on the 10th of March reached the conclusions of their advises, which on the 17th of March were sent to Exeter. But their counsels also arrived too late, for the ministers had been already dismissed. Among the non-subscribers at the Salters' Hall Conference were two leading Congregationalists Isaac Watts and Philip Doddridge, and both adopted positions which were entirely pleasing to strictly orthodox Independents. Isaac Watts, who clearly saw himself as an orthodox trinitarian and leave us in no doubts as to his personal belief in the Deity of Christ, refused in 1728 an invitation to the pastorate of their heresy-conscious Castle Gate church in Nottingham (Watts 1978: 380). However, towards his last years he spent some time worrying about the Trinity. Macleod explains that the real problem is found in Watts' speculations on the Person of the Son. He had serious misgivings about the eternal sonship of Christ, and often expressed himself on this issue in language reminiscent of the 4th century Arians (Macleod 1996: 129).

On the other hand, as Macleod maintains, he was fully aware of the defects of Arianism and argued strongly against it (Macleod 1996: 128). Nevertheless, we understand that he had a curiously conciliatory approach to Arianism and was also reluctant to confront Arianism head-on. Instead he always felt bound to reassure them that he did not expect them to accept the whole orthodox package. In fact, in his treatise The Arian Invited to the Orthodox Faith, Watts was struggling to find common ground with Arianism, to be as conciliatory as possible and to meet Arian scruples as far as he could. Such behaviour might lead us to think that his next step would be a full compliance with Arianism, but Watts did not take that step.

The explanation offered for his behaviour is that in his determination to avoid bondage to ancient creedal formularies, Watts embarked upon the very kind of speculation which had made these formularies necessary in the first place. 
Doddridge is another man associated with Arianism in English nonconformity, who alongside Watts 'endeavoured to find a middle term between Trinitarianism and Arianism'. [Quoted by Macleod (1996: 131) from William Robertson Nicoll.] Although taken by some scholars to be an Arian, Macleod sets to prove with quotes from The Family Expositor that Doddridge is 'aggressively orthodox' in his treatment on the Deity of Christ. Doddridge shows himself the same character in his more scholarly treatment $A$ Course of Lectures on the Principal Subjects in Pneumatology, Ethics and Divinity. I these lectures, as before, Doddridge clearly states his arguments for Christ's Deity, but it is also here that a hint is given as to why he was suspected of heresy. The issue which Doddridge does not clarify is with respect to the relation between Christ and the divine nature, on the one hand and on the other Doddridge endorsed Watts' idea of the pre-existence of the human soul of Christ (Macleod 1996: 132).

It is also observed that Doddridge did not show enough commitment to the question of the personality of the Holy Spirit and did not exhibit a definite dogmatic style of theological teaching. He showed neutrality on the subjects and encouraged freedom of inquiry on the part of the students. But it is argued that as he was working in an environment where young men were being trained for the ministry, he ought to have been more dogmatic on subjects such as the Deity of Christ and the personality of the Holy Spirit, and thus offer the students clear guidance on fundamental Christian doctrines (Macleod 1996: 133).

In the light of all these we see that in time the fears of the Subscribers that the attitude adopted by the Non-subscribers would lead to Unitarianism were justified. By the end of the century there were 200 Unitarian chapels in England and the movement as a whole had acquired significant influence through such men as Joseph Priestley (1733-1804), whose spiritual pilgrimage saw him move from Calvinism to Arminianism to Arianism (Macleod 1996: 127).

From 78 London Dissenting ministers who are known to have been Subscribers at Salters' Hall, 30 were Presbyterians, 28 Congregationalists, 14 Particular Baptists, 1 General Baptist, and 5 of unknown affiliation. From 73 Non-subscriber ministers, 47 were Presbyterians, 9 Congregationalists, 14 General Baptists, 2 Particular Baptists and 1 of uncertain affiliation.

So, we notice that most Presbyterian and General Baptist ministers took their stand on the sufficiency of Scripture, the majority of Congregationalists and Particular Baptists insisted on subscription to a Trinitarian creed. Within a century most Presbyterian meetings and many of the General Baptist churches connected with the General Assembly had become Unitarian, while the Congregational and Particular Baptist churches not only remained Trinitarian but continued to honour the theology of John Calvin. In 
the case of the Presbyterians it must be emphasized that the process by which many meetings passed from Calvinism through Arminianism to Unitarianism was one of slow evolution, not revolution, and that although the development had begun well before 1730, the outcome was by no means obvious by that date (Watts 1978: 381).

In conclusion, what can we say about the effects produced by the Salters' Hal episode? First, it must be said that it was a seismic forecast of the theological chasm which would ultimately open up between the Presbyterian and Congregational denominations, the first cracks of which had appeared at the time of the Richard Davis case 30 years before. The Independents, which under the Commonwealth had stood for toleration and variety now came to mean theological conservatism.

The Presbyterians, which theologically speaking, had meant doctrinal consensus, now stood for latitude. How can such a paradox be explained? It is explained by the differing ecclesiastical traditions of the two denominations.

Though the Presbyterian ministers of the Interregnum had always been intolerant of separatism outside the established church, they had always maintained that the church on earth must consist of both saved and damned, for God's decrees of election and reprobation could not be known to man. Though the Presbyterians of the early eighteenth century set higher moral standards, they were tolerant towards those of heterodox beliefs. There were some Presbyterian ministers who admitted all sorts of persons that will but say they are Christians into their communion, whether they are Arminians, Calvinists, Freethinkers, Arians or Socinians, it is all one to them, and their pulpits too are ready to receive ministers of the same sake.

On the other hand, as far as the Congregational wing of Independency was concerned, their advocacy of toleration was a product not of their theology but of their circumstance: when in a position of power, as in Massachusetts, the Congregationalists showed themselves as ready as the Presbyterians to use the authority of the state to enforce outward religious conformity.

But the Congregationalists were more confident than the Presbyterians that they could distinguish between the elect and the reprobate on earth and were always determined in their efforts to restrict church membership to the former. They insisted on religious experience as the condition for church membership, rather than on a degree of knowledge which the Presbyterians used as the test for admission to communion. The English Congregationalists, for the most part, succeeded in keeping out of their churches people who might seek to judge Calvinist orthodoxy at the bar of reason.

Bogue and Bennett explain that the proceedings of the London ministers excited the most eager attention of the Dissenters in every part of Eng- 
land. They note that 'the difference of judgment which took place, as to the manner of giving advice to their brethren at Exeter, broke to pieces longcontracted friendships among the ministers who took different sides, produced suspicious jealousies of each other's principles, and created a party spirit, and alienation of heart between those who had formerly lived in the most endearing cordiality' (Bogue and Bennett 2001: 133, 137). And then conclude that 'it would have been better, if they had listened to the advice of Mr. Bradbury, who proposed, that instead of meeting as a council, they should repeatedly assemble for fasting and prayer; that they should then choose a few of the wisest and best of their number, and send them down to Exeter, to see and hear upon the spot, and give such counsel for the maintenance of truth and harmony, as an accurate and personal knowledge of the whole should dictate' (Bogue and Bennett 2001: 137).

And in their final conclusion they show that according to the sentiment which has generally prevailed, the subscribing ministers were wholly in the wrong: they are charged with a load of guilt; they are said to deny the sufficiency of the sacred Scriptures, to be advocates for human authority in spiritual things, and enemies to religious liberty and free inquiry (Bogue and Bennett 2001: 133).

\section{Conclusions}

As we draw towards the end of our consideration of Arianism in English Nonconformity, we cannot avoid but to conclude that at that time in every part of England, Arianism was not only embraced, but openly acknowledged by most of the Presbyterian ministers. The heresy polluted some of the London pulpits; in Lancashire it was prevalent, and in the counties to the south; it gained ground also in the west, whence it first sprang. That generation of ministers, who contended so zealously for the orthodox faith, had finished their labours, and received from their Lord a dismissal into eternal rest.

Those champions among the laity who, at the beginning of the controversy, stood up so firmly for the truth, had entered as well into the joy of their Lord. Though their children continued Dissenters, too many of them did not possess the same sentiments or spirit. Among those who succeeded these ministers were too many who embraced the Arian creed. To this unhappy change contributed the example and conversation as well of many from the younger Presbyterian ministers. In one or two seminaries, the tutors were accused of giving countenance to the heresy among the students.

In consequence Arianism spread far and wide in the Presbyterian congregations, both among the ministers and the people. This unhappy controversy proved the grave of the Presbyterian congregations, and of those of 
the General Baptists. The effects of Arianism, though at first scarcely visible, gradually produced desolation and death.

\section{Bibliography}

Bavinck H (1956) Our Reasonable Faith. Grand Rapids: Eerdmans.

Berkhof L (1963) Systematic Theology. Edinburgh: Banner of Truth.

Berkhof L (1959) The History of Christian Doctrines. Michigan: Eerdmans.

Bogue D and Bennett J (2001) History of Dissenters, From the Revolution to the year 1838, volume 2. Stoke-on-Trent: Tentmaker Publications.

Bray G (1984) Creeds, Councils and Christ. Leicester: Inter-Varsity Press.

Calvin John (1960) Institutes of the Christian Religion. In McNeill JT (ed), Lewis FB (trans) The Library of Christian Classics, volume 1, book 1, chapter XIII. Philadelphia, PA: The Westminster Press.

Elwell WA (ed) (2000) Evangelical Dictionary of Theology. Grand Rapids, MI: Baker.

Eveson P (2000) The Case for Forensic Justification in John Owen. In Seeing the Lord. Published by The Westminster Conference.

Grudem W (1994) Systematic Theology: An Introduction to Biblical Doctrine. Leicester: Inter-Varsity Press.

Kelly J ND (1960) Early Christian Creeds. London: Longmans.

Leith JH (1978) Introduction to the Reformed Tradition. Edinburgh: The Saint Andrew Press.

Macleod D (1996) God or god? Arianism, Ancient and Modern. The Evangelical Quarterly 68(2): n.p.

McGrath AE (1998) Historical Theology. Oxford: Blackwell.

Needham NR (2000) Part II: The Middle Ages. In 2000 years of Christ's Power. London: Grace Publications.

Niesel W (1980) The Theology of Calvin Knight H (trans). Grand Rapids, MI: Baker.

Trueman CR (1998) The Claims of Truth, Owen's Trinitarian Theology. Carlisle: Paternoster Press.

Turretin F (1992) Institutes of Elenctic Theology, volume 1, Ginger GM (trans) and Dennison JT Jr (ed). Phillipsburgh, PA: P\&R.

Watts MR (1978) The Dissenters from Reformation to the French Revolution. Oxford: Clarendon Press.

[This article was published previously is Moga D (2008) Studies in Historical Theology. Oradea: Emanuel University Press, pp. 7-36.] 